\title{
Effects of volume resuscitation on the microcirculation in animal models of lipopolysaccharide sepsis: a systematic review
}

Nchafatso G. Obonyo ${ }^{1,2,3}$, Jonathon P. Fanning ${ }^{1,3}$, Angela S. Y. Ng ${ }^{1,3}$, Leticia P. Pimenta ${ }^{1}$, Kiran Shekar ${ }^{1,3}$, David G. Platts ${ }^{1,3}$, Kathryn Maitland ${ }^{2,4}$ and John F. Fraser ${ }^{1,3^{*}}$

\section{* Correspondence:}

fraserjohn001@gmail.com

${ }^{1}$ Critical Care Research Group, The

Prince Charles Hospital, Brisbane,

Queensland, Australia

${ }^{3}$ School of Medicine, University of

Queensland, Brisbane, Queensland,

Australia

Full list of author information is

available at the end of the article

\section{Springer Open}

\begin{abstract}
Background: Recent research has identified an increased rate of mortality associated with fluid bolus therapy for severe sepsis and septic shock, but the mechanisms are still not well understood. Fluid resuscitation therapy administered for sepsis and septic shock targets restoration of the macro-circulation, but the pathogenesis of sepsis is complex and includes microcirculatory dysfunction.
\end{abstract}

Objective: The objective of the study is to systematically review data comparing the effects of different types of fluid resuscitation on the microcirculation in clinically relevant animal models of lipopolysaccharide-induced sepsis.

Methods: A structured search of PubMed/MEDLINE and EMBASE for relevant publications from 1 January 1990 to 31 December 2015 was performed, in accordance with PRISMA guidelines.

Results: The number of published papers on sepsis and the microcirculation has increased steadily over the last 25 years. We identified 11 experimental animal studies comparing the effects of different fluid resuscitation regimens on the microcirculation. Heterogeneity precluded any meta-analysis.

Conclusions: Few animal model studies have been published comparing the microcirculatory effects of different types of fluid resuscitation for sepsis and septic shock. Biologically relevant animal model studies remain necessary to enhance understanding regarding the mechanisms by which fluid resuscitation affects the microcirculation and to facilitate the transfer of basic science discoveries to clinical applications.

Keywords: Lipopolysaccharide, Sepsis, Septic shock, Fluid resuscitation, Microcirculation, Intravital fluorescence microscopy, Oxygen extraction, Laser Doppler flowmetry,

Sidestream dark-field videomicroscopy, Laser speckle imaging

\section{Review}

Introduction

Sepsis is a syndrome induced by infection that is characterized by physiologic, pathologic, and biochemical abnormalities [1], thus causing a substantial primary disease burden and co-morbidity [2]. Treatment guidelines globally recommend correction of haemodynamic abnormalities via the rapid administration of fluid boluses and blood transfusion to

(c) The Author(s). 2016 Open Access This article is distributed under the terms of the Creative Commons Attribution 4.0 International License (http://creativecommons.org/licenses/by/4.0/), which permits unrestricted use, distribution, and reproduction in any medium, provided you give appropriate credit to the original author(s) and the source, provide a link to the Creative Commons license, and indicate if changes were made. 
restore macro-circulatory parameters such as cardiac output and blood pressure [3-9]. Whilst there is general consensus on the key pillars of sepsis management-such as early recognition, source control, and timely antibiotic administration-there are a number of controversial issues surrounding volume resuscitation (type of fluid, dose, and rate). Treatment guidelines focus upon the normalization of macro-circulatory perturbations, with less attention to restoring microcirculatory dysfunction, which can only be resuscitated in the early period and has been shown to occur early in the disease process [10] and to persist in the later stages of volume-resuscitated sepsis and septic shock [10-18].

The microcirculation is an elaborate network of blood vessels, comprised of arterioles, venules, and capillaries that are lined with a dynamic endothelial-glycocalyx layer [19]. This network together forms the largest organ system in the body [20]. Microcirculatory function of coupling the delivery of metabolic substrates to respiring tissues, relative to requirements, and the removal of metabolic products, has been shown to be the main prerequisite for adequate tissue oxygenation and organ function [17]. Sepsis causes endothelial activation and the breakdown and shedding of the glycocalyx, leading to microcirculatory dysfunction. Progressive microvascular and organ dysfunction in sepsis and septic shock have been described extensively in literature [16-18, 21-34], and impaired microcirculatory function has been shown to be an independent predictor of mortality $[11,26]$. Whilst it has been postulated that resuscitation of sepsis by rapid fluid administration may worsen microcirculatory dysfunction, there have been reports of glycocalyx stabilization by fresh frozen plasma (FFP) [35]. Increased microcirculatory flow during resuscitation for sepsis has been associated with reduced organ failure at $24 \mathrm{~h}$ without substantial differences in global haemodynamics, supporting the hypothesis that targeting microcirculation distinct from the macro-circulation could potentially improve organ failure in sepsis [36] and hence have a prognostic role and be the target of therapeutic interventions [37].

Description of microcirculatory alterations in septic animal models has been done using several techniques such as intravital microscopy, laser speckle imaging, laser Doppler flowmetry [32] and videomicroscopic techniques, such as orthogonal polarization spectroscopy and sidestream dark-field imaging [38]. Intravital microscopy entails imaging live animals at microscopic resolution [39] via trans-illumination or epi-illumination and recording pictures by means of low-light level silicon-intensified or charge-coupled video cameras [40]. It enables the in vivo morphological viewing of the microcirculation, as well as the quantification of micro-haemodynamic functional capillary density (FCD), endothelial integrity and cellular interactions when used in combination with fluorescent markers [40]. Laser speckle is an interference pattern produced by light reflected or scattered from different parts of a laser-illuminated surface [41]. The motion of particles in the laser-illuminated medium causes spatial and temporal fluctuations, producing an interference pattern consisting of bright and dark areas (i.e., the so-called speckles) visualized on a detector [42]. Laser Doppler produces an indirect measure of flow by quantifying shift in the Doppler frequency of a monochromatic laser light signal (helium-neon laser, $632.8 \mathrm{~nm}$ ) that is scattered by red blood cells moving through the microcirculation [41, 43]. Light which is backscattered from moving erythrocytes undergoes a shift in frequency that is proportional to their velocity in accordance to the Doppler principle [44], hence making it possible to obtain reproducible measurements of blood flow at a single spot defined by the incident and 
Doppler-shifted reflected light [45]. Sidestream dark-field (SDF) imaging technology is based on improved orthogonal polarized spectral (OPS) imaging, whereby concentrically placed light-emitting diodes (LEDs) provide pulsed synchronous illumination of the microcirculation at a central wavelength of $530 \mathrm{~nm}$ for optimal absorption by the haemoglobin in red blood cells, independent of the oxygenation state [38].

Volume resuscitation for treatment of septic shock has been the standard of care recommended by guidelines following evidence of reduction in persistent hypovolaemia and improved survival $[7,9,46,47]$. These guidelines have been mainly based on observational studies and expert opinion, in the absence of supportive evidence from randomized controlled trials. Consequently, different types of fluid are used in resuscitation including crystalloids, colloids and blood transfusion.

Generally, there is a paucity of animal model studies on effects of fluid resuscitation on the microcirculation. A comparison of crystalloid and colloid in cecal ligation and puncture-induced sepsis in rodents concluded that crystalloid infusion produced better microcirculatory function as well as mortality benefit [48], with growing interest in comparison of fluid types $[49,50]$ and early versus late resuscitation in experimental animal models [51,52]. Clinically, there is still controversy on the choice of resuscitation fluids. The trial on Early Goal Directed Therapy (EGDT) for treatment of sepsis and septic shock [47] was found to have no mortality benefit in subsequent trials [53-55]. However, lower mortality in septic patients resuscitated with albumin-containing solutions had been reported in a meta-analysis [56] but there was no significant mortality benefit of albumin compared to saline in the Fluid Expansion as Supportive Therapy (FEAST) randomized controlled trial [57]. A Cochrane meta-analysis comparing colloid to crystalloid fluid resuscitation, in a heterogeneous group of critically-ill patients, failed to demonstrate any tangible benefits on mortality [58]. Emerging research data highlights an urgent need to review volume resuscitation strategies and adjunct vasopressor use in sepsis and septic shock.

Mechanistic research is therefore essential to define cause and effect. However, whilst animal research is advocated for investigating mechanisms of disease process and testing therapeutic interventions, discordant comparisons of treatment effects between animal experiments and clinical trials have arisen, due to the failure of animal models to adequately mimic clinical disease [59].

The aim of this review was to identify clinically relevant experimental animal models that have been used to assess the microcirculatory effects of fluid resuscitation treatment for lipopolysaccharide (LPS)-induced sepsis. We therefore examined the evidence available on the effects of fluid resuscitation on the microcirculation in LPSinduced sepsis and septic shock.

\section{Methods}

\section{Search strategy}

A systematic search was conducted in two indexed online databases-PubMed/MEDLINE and EMBASE-for articles describing the microcirculation in sepsis and septic shock, published from 1 January 1990, through 31 December 2015, in accordance with PRISMA guidelines [60]. In PubMed/MEDLINE, the search terms used in [MeSH Terms] or [All Fields] were 'sepsis' OR 'septicaemia' OR 'septic shock' AND 'microcirculation'. In 
EMBASE, the keywords used were '(microcirculation AND sepsis),'(microcirculation AND septicaemia)', and '(microcirculation AND septic shock)'.

\section{Selection criteria}

All abstracts identified through the searches were compiled in Endnote ${ }^{\circ}$ (Thomson Reuters) and screened for relevance, after removing duplicates. Publications were eligible for inclusion in the review if they were conducted on animal models of LPSinduced sepsis and septic shock and compared different types of fluid resuscitation, with or without a control group. Full published manuscripts of studies considered relevant were retrieved and reviewed. Cited publications within the retrieved articles were also screened for relevance. We restricted our review to studies assessing the effects of fluid resuscitation on the microcirculation in sepsis/septic shock and articles either written in English or translated into English.

\section{Results}

A total of 2346 articles were retrieved from our search of published literature. Initial screening to remove duplicates and studies with no apparent relevance yielded 912 unique articles (Fig. 1). There has generally been a gradual increase in the number of published papers on sepsis and the microcirculation over the last 25 years (Fig. 2). After excluding non-experimental review articles, clinical studies and pre-clinical experiments investigating therapeutic interventions other than volume resuscitation, 11 studies were found to be relevant to the assessment of microcirculatory effects of volume resuscitation in animal models of LPS-induced sepsis. The methods used for quantification of microcirculation function, type and volume of resuscitation fluid administered and the resultant microcirculatory effects in the retrieved studies are presented in Table 1.

\section{Study characteristics}

The featured 11 studies involved both small rodent models, included two hamster studies $(n=58)$ [61, 62], and two rat studies $(n=57)$ [52, 63], and large mammal models, which included three pig $(n=64)[51,64,65]$, two dog $(n=28)[66,67]$ and two sheep studies $(n=27)[15,68]$. In each instance, sepsis was induced by intravascular LPS infusion post induction of appropriate anaesthesia.

\section{Microcirculatory assessment and outcome}

In the small rodent models, microcirculatory function was assessed primarily by intravital fluorescence microscopy [61-63], with one study using laser speckle imaging [52]. Laser Doppler flowmetry and/or videomicroscopic sidestream dark-field (SDF) imaging were largely used for microcirculatory assessments in the larger mammalian models $[15,51,65,67]$. One study utilized indirect quantification of oxygen extraction to assess microcirculatory function [66]. Six studies reported improved blood flow in the microcirculation and reduced extravasation of plasma following fluid resuscitation [61-64, 66, 67]. One study reported improvement of microvascular blood flow and oxygenation with overall negative fluid balance in sepsis [65], whilst three studies documented persistent microcirculatory dysfunction with volume resuscitation $[15,51,52]$. One study exhibited improved sublingual and serosal intestinal microcirculation, but persistent dysfunction in the intestinal mucosal villi within the same sepsis model resuscitated with hydroxyethyl starch (HES) [68]. None of the studies presented in this review used blood transfusion for volume resuscitation. Differences in the animal species, size of the study arms, methods 


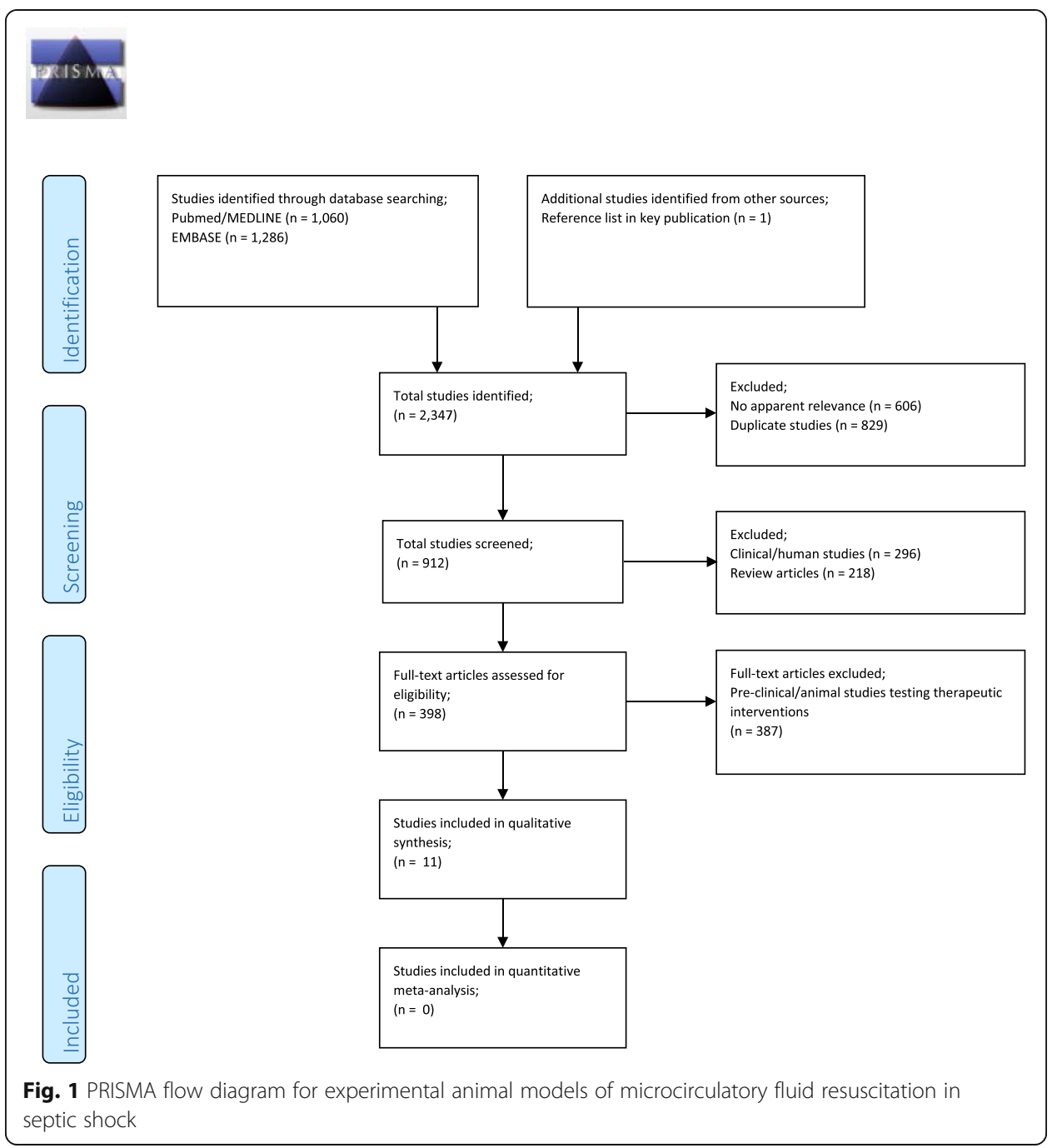

of microcirculatory assessment, types and volume of fluid resuscitation administered and the experimental time-points for the induction of sepsis and resuscitation precluded any quantitative meta-analysis.

\section{Discussion}

Preclinical animal research is a necessary adjunct to clinical trials as we seek to improve our mechanistic understanding of the pathophysiology of sepsis and the consequent effects of volume resuscitation. Different outcomes in the animal studies presented in this review reflect a state of equipoise regarding the effectiveness of volume resuscitation on the microcirculation in the management of sepsis and septic shock.

The aetiology of microcirculatory dysfunction seen during sepsis is multi-factorial, including increased blood viscosity, reduced red blood cell deformability [69], neutrophil activation [70] and impaired vascular auto-regulation [20], leading to inadequate oxygen delivery to tissues. The mechanical properties of red blood cells are altered by effects of endotoxin binding directly to the red blood cells [71]. Increased vascular permeability occurs as a result of endothelial cell damage. Disruption of the endothelial- 


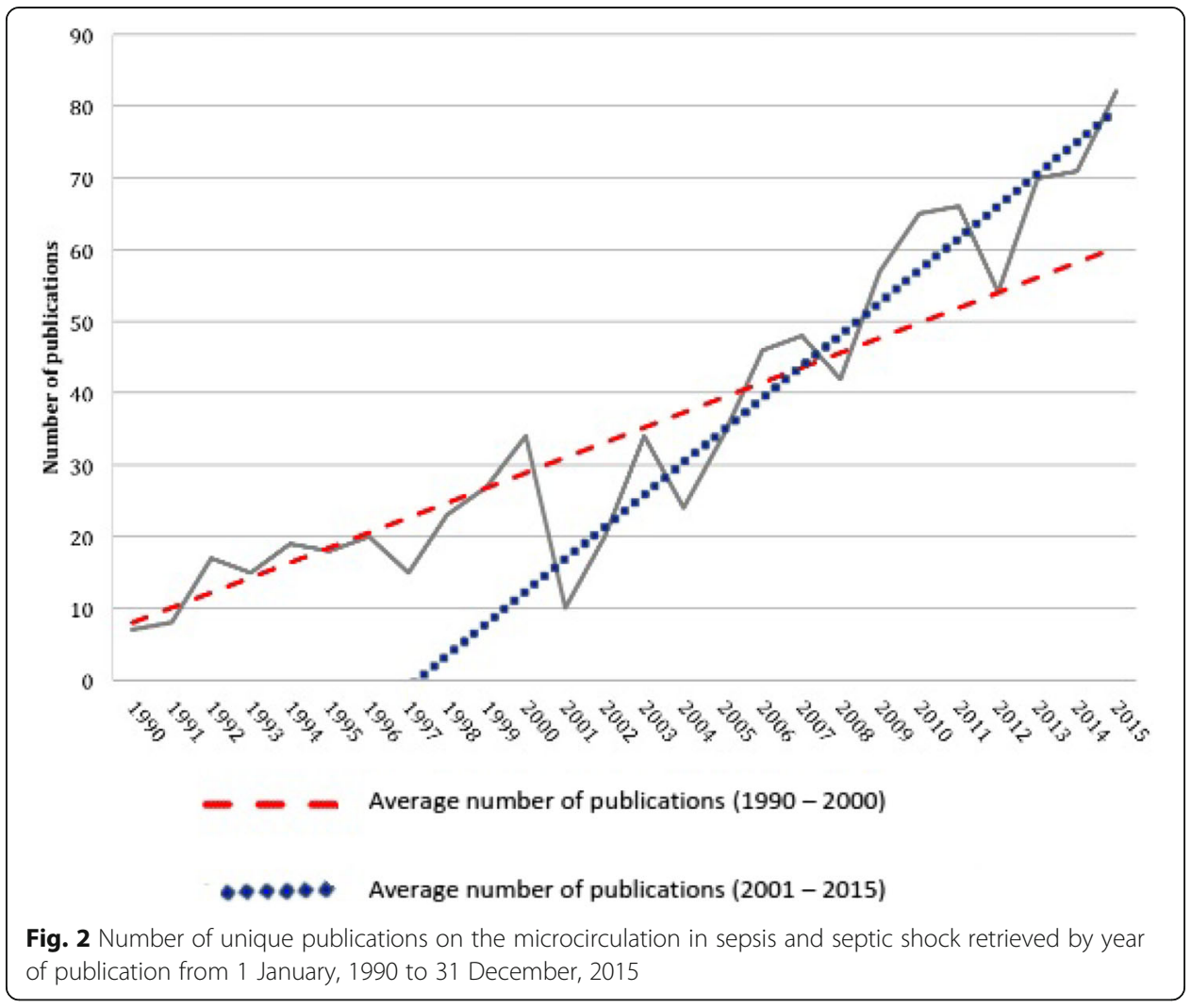

glycocalyx barrier exposes endothelial cell surface adhesion molecules that trigger the activation of mast cells, and the adhesion of platelets and white blood cells, thereby causing further inflammation [72] and nitric oxide production [73]. Nitric oxide, in turn, induces the relaxation of vascular smooth muscle, leading to increased blood flow shear stress and the production of pro-inflammatory cytokines, further worsening endothelial inflammation. Rapidly administered volume resuscitation therapy in the setting of a damaged endothelial-glycocalyx barrier alters cardiovascular haemodynamics [51] and may further exacerbate interstitial oedema directly by increasing intravascular hydrostatic pressure and indirectly through osmotic diffusion across the concentration gradient of leaked solutes.

Three of the studies presented in this review used intravital microscopy to assess the microcirculation, two demonstrating an improvement with fluid administration [61, 63] and one an improvement with hydroxyl-ethyl starch but not saline administration [62]. Only one study used laser speckle microcirculatory imaging [52] and showed no improvement following fluid administration. Three studies presented in this review used laser Doppler imaging and showed improved microcirculatory reactivity with fluid administration [64, 65, 67]. Microcirculatory assessment by sidestream dark-field imaging presented in this review exhibited heterogeneous effects in different tissues in one study [68], but no improvement in another [51]. Comparisons of different microcirculatory imaging techniques have been reported in literature [41, 74-76]. Investigators who conducted a comparative study on cochlear blood flow concluded that intravital microscopic measurements were more sensitive than laser Doppler measurements [77]. However, comparing the microcirculatory results attained with different methods is a 
Table 1 Animal model studies assessing effects of volume resuscitation on the microcirculation in lipopolysaccharide-induced sepsis

\begin{tabular}{|c|c|c|c|c|c|c|c|}
\hline Author & $\begin{array}{l}\text { Publication } \\
\text { year }\end{array}$ & $\begin{array}{l}\text { Animal } \\
\text { species }\end{array}$ & $\begin{array}{l}\text { Number } \\
\text { per arm }\end{array}$ & $\begin{array}{l}\text { Methods used for } \\
\text { microcirculation assessment }\end{array}$ & $\begin{array}{l}\text { Type and mean volumes } \\
\text { administered }\end{array}$ & Principal findings & Motivation for study \\
\hline $\begin{array}{l}\text { Maciel } \\
\text { et al. [66] }\end{array}$ & 1998 & Dog & 7 & $\begin{array}{l}\text { Quantification of oxygen } \\
\text { extraction: } \\
\text { Microcirculation was assessed } \\
\text { indirectly by quantifying oxygen } \\
\text { extraction in gas analyzers sampling } \\
\text { to measure expired oxygen fraction } \\
\text { and end-tidal carbon dioxide tension }\end{array}$ & $\begin{array}{l}\text { a) } 291 \pm 62 \mathrm{~mL} \text { (control } \\
\text { group, isotonic saline } 0.9 \% \text { ) } \\
\text { b) } 123 \pm 12 \mathrm{~mL} \text { (treatment group, } \\
\text { hypertonic saline } 7.5 \% \text { ) }\end{array}$ & $\begin{array}{l}\text { Hypertonic saline } \\
\text { resuscitation increases } \\
\text { oxygen extraction compared } \\
\text { to isotonic saline by improved } \\
\text { microvascular perfusion }\end{array}$ & $\begin{array}{l}\text { Assess whether a solution } \\
\text { of hypertonic saline hydroxyl- } \\
\text { ethyl starch can increase } \\
\text { tissue oxygen extraction in } \\
\text { endotoxic shock }\end{array}$ \\
\hline $\begin{array}{l}\text { de Carvalho } \\
\text { et al. [61] }\end{array}$ & 1999 & Hamster & 6 & $\begin{array}{l}\text { Intravital fluorescence microscopy: } \\
\text { Microcirculation was assessed by } \\
\text { intravital microscopy of cheek pouch } \\
\text { tissue and counting extravasation sites } \\
\text { of fluorescein isothiocyanate-labelled, } \\
\text { FITC dextran }\end{array}$ & $\begin{array}{l}\text { a) No sepsis control; } 0.35 \\
\mathrm{~mL} / 100 \mathrm{~g} \text { body weight for } \\
4 \mathrm{~min}, 7.5 \% \text { hypertonic saline } \\
\text { b) and c) LPS groups } 1 \text { and } 2 \\
\text { (no volume resuscitation controls) } \\
\text { d) HS group; } 0.35 \mathrm{~mL} / 100 \mathrm{~g} \text { body } \\
\text { weight for } 15 \mathrm{~min} \text { prior to LPS } \\
\text { e) HSD group; } 0.35 \mathrm{~mL} / 100 \mathrm{~g} \\
\text { body weight for } 15 \text { min prior } \\
\text { and } 4 \text { min after the induction } \\
\text { of LPS }\end{array}$ & $\begin{array}{l}\text { Hypertonic saline with and } \\
\text { without dextran reduce local } \\
\text { and systemic endotoxin- } \\
\text { inducedplasma leakage }\end{array}$ & $\begin{array}{l}\text { Assess effect of hypertonic } \\
\text { saline with and without } \\
\text { dextran on endotoxin-induced } \\
\text { vascular permeability in the } \\
\text { cheek pouch microcirculation } \\
\text { compared to systemically }\end{array}$ \\
\hline $\begin{array}{l}\text { Zhang } \\
\text { et al. [67] }\end{array}$ & 1999 & Dog & 7 & $\begin{array}{l}\text { Laser Doppler perfusion monitoring: } \\
\text { Microcirculation was assessed by laser } \\
\text { Doppler measurements obtained from } \\
\text { ileum and liver microvasculature which } \\
\text { were then used to calculate an arbitrary } \\
\text { red blood cell flux index in } 1 \mathrm{~mm}^{3} \text { of } \\
\text { tissue in each organ }\end{array}$ & $\begin{array}{l}\text { a) No fluid resuscitation control } \\
\text { group } \\
\text { b) } 20 \mathrm{~mL} / \mathrm{kg} / \mathrm{h} 0.9 \% \text { normal saline }\end{array}$ & $\begin{array}{l}\text { Microvascular depression in } \\
\text { endotoxaemia was more } \\
\text { severe in the liver than in } \\
\text { the intestinal mucosa but } \\
\text { increased similarly after initial } \\
\text { resuscitation }\end{array}$ & $\begin{array}{l}\text { Compare alterations in } \\
\text { hepatic and intestinal } \\
\text { mucosal microcirculation } \\
\text { during the acute phase of } \\
\text { blood flow reduction in } \\
\text { endotoxic shock and the } \\
\text { effect of fluid resuscitation }\end{array}$ \\
\hline $\begin{array}{l}\text { Oi et al. } \\
\text { [64] }\end{array}$ & 2000 & Pig & $(7,8$ and 9$)$ & $\begin{array}{l}\text { Laser Doppler flowmetry: } \\
\text { Microcirculation was assessed by } \\
\text { intestinal blood flow laser Doppler } \\
\text { measurements expressed in arbitrary } \\
\text { laser Doppler perfusion units, PU }\end{array}$ & $\begin{array}{l}\text { a) No fluid resuscitation control } \\
\text { group } \\
\text { b) } 4 \mathrm{~mL} / \mathrm{kg} \text { over } 10 \text {-min } \\
\text { (0.9\% isotonic saline in } 6 \% \\
\text { dextran } 70 \text {, ISD) } \\
\text { c) } 4 \mathrm{~mL} / \mathrm{kg} \text { over } 10 \text {-min } \\
(7.5 \% \text { hypertonic saline } \\
\text { in } 6 \% \text { dextran } 70, \mathrm{HSD})\end{array}$ & $\begin{array}{l}\text { Hypertonic saline improved } \\
\text { intestinal mucosal blood flow } \\
\text { better than isotonic saline and } \\
\text { no resuscitation }\end{array}$ & $\begin{array}{l}\text { Compare effects of } \\
\text { hypertonic saline, isotonic } \\
\text { saline and no resuscitation in } \\
\text { endotoxin shock }\end{array}$ \\
\hline
\end{tabular}


Table 1 Animal model studies assessing effects of volume resuscitation on the microcirculation in lipopolysaccharide-induced sepsis (Continued)

\begin{tabular}{|c|c|c|c|c|c|c|c|}
\hline $\begin{array}{l}\text { Hoffmann } \\
\text { et al. [62] }\end{array}$ & 2002 & Hamster & $(7,6$ and 8$)$ & $\begin{array}{l}\text { Intravital fluorescence microscopy: } \\
\text { Microscopy was assessed by } \\
\text { intravital microscopy on dorsal } \\
\text { skin-fold chamber and } \\
\text { computation of; } \\
\text { (a) Functional capillary density, FCD } \\
\text { (i.e. length of all erythrocyte- } \\
\text { perfused nutritive capillaries per } \\
\text { observation area) } \\
\text { (b) Vascular permeability quantified } \\
\text { by extravasation of fluorescein } \\
\text { isothiocyanate-labelled, FITC } \\
\text { dextran }\end{array}$ & $\begin{array}{l}\text { a) No fluid resuscitation control } \\
\text { group } \\
\text { b) } 16 \mathrm{~mL} / \mathrm{kg} \mathrm{HES} \\
\text { c) } 66 \mathrm{~mL} / \mathrm{kg} 0.9 \% \text { isotonic saline }\end{array}$ & $\begin{array}{l}\text { Synthetic hydroxyethyl starch } \\
\text { (HES) preserved the functional } \\
\text { capillary density (FCD) compared } \\
\text { to saline and no resuscitation }\end{array}$ & $\begin{array}{l}\text { Assess and compare effects } \\
\text { of different volume support } \\
\text { administered in endotoxin- } \\
\text { induced microcirculatory } \\
\text { disorders }\end{array}$ \\
\hline $\begin{array}{l}\text { Anning } \\
\text { et al. [63] }\end{array}$ & 2004 & Rat & $(5,6$ and 7$)$ & $\begin{array}{l}\text { Intravital fluorescence microscopy: } \\
\text { Microcirculation was assessed by } \\
\text { intravital microscopy on an } \\
\text { exteriorised loop of intestine and } \\
\text { its associated mesentry and } \\
\text { computation of; } \\
\text { (a) Measurements of the rolling } \\
\text { velocity of all leucocytes } \\
\text { entering a microvessel and } \\
\text { leucocyte flux (i.e. the number } \\
\text { of rolling leucocytes) were } \\
\text { defined as adherent if stationary } \\
\text { for }>30 \text { s } \\
\text { (b) Vascular permeability quantified } \\
\text { by extravasation of fluorescein } \\
\text { isothiocyanate-labelled bovine serum } \\
\text { albumin (FITC-BSA) }\end{array}$ & $\begin{array}{l}\text { a) No fluid resuscitation control } \\
\text { group } \\
\text { b) } 16 \mathrm{~mL} / \mathrm{kg} / \mathrm{h} \text { (0.9\% saline) } \\
\text { c) } 16 \mathrm{~mL} / \mathrm{kg} / \mathrm{h} \text { ( } 5 \% \text { albumin) }\end{array}$ & $\begin{array}{l}\text { Lipopolysaccharide-induced } \\
\text { albumin flux, leucocyte rolling } \\
\text { and adhesion in the } \\
\text { microcirculation was reduced } \\
\text { by both } 0.9 \% \text { saline and } 5 \% \\
\text { human albumin solutions }\end{array}$ & $\begin{array}{l}\text { Assess effect of fluid } \\
\text { administration on } \\
\text { lipopolysaccharide-induced } \\
\text { changes in mesenteric } \\
\text { microcirculation }\end{array}$ \\
\hline $\begin{array}{l}\text { Dubin } \\
\text { et al. [68] }\end{array}$ & 2008 & Sheep & 7 & $\begin{array}{l}\text { Sidestream dark-field imaging: } \\
\text { Microcirculation was assessed by } \\
\text { the following measurements } \\
\text { obtained from sublingual mucosa } \\
\text { and intestinal mucosa and serosa } \\
\text { (three different regions within each }\end{array}$ & $6 \% \mathrm{HES}^{\mathrm{a}}$ & $\begin{array}{l}\text { Hydroxyethyl starch fluid } \\
\text { resuscitation restored } \\
\text { microcirculation in the } \\
\text { sublingual and intestinal serosa } \\
\text { but not in the intestinal mucosa }\end{array}$ & $\begin{array}{l}\text { Test hypothesis that persistent } \\
\text { villi hypoperfusion explains } \\
\text { intramucosal acidosis after } \\
\text { resuscitation for } \\
\text { endotoxaemic shock }\end{array}$ \\
\hline
\end{tabular}


Table 1 Animal model studies assessing effects of volume resuscitation on the microcirculation in lipopolysaccharide-induced sepsis (Continued)

\begin{tabular}{|c|c|c|c|c|c|c|c|}
\hline & & & & 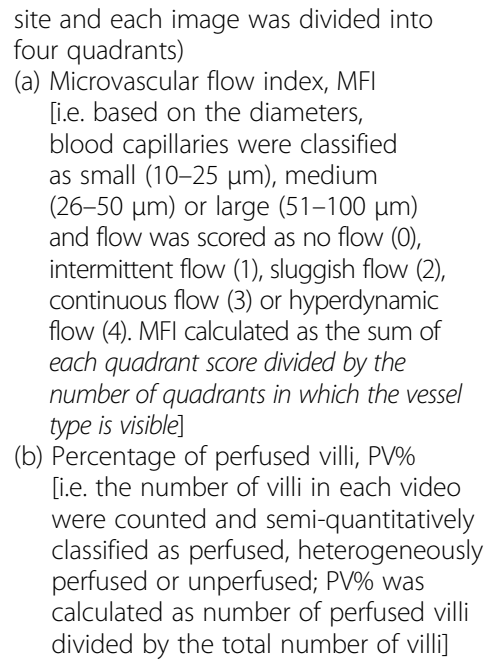 & & & \\
\hline $\begin{array}{l}\text { Legrand } \\
\text { et al. [52] }\end{array}$ & 2011 & Rat & (5 and 7) & $\begin{array}{l}\text { Laser speckle imaging: } \\
\text { Microcirculation was assessed by the } \\
\text { following measurements obtained } \\
\text { from the renal cortex } \\
\text { (a) Microvascular perfusion histograms } \\
\text { based on laser speckle imaging } \\
\text { perfusion maps } \\
\text { (b) Microvascular oxygen tension } \\
\text { histograms based on phosphorimetry }\end{array}$ & $\begin{array}{l}\text { a) Early resuscitation group } \\
40 \mathrm{~mL} / \mathrm{kg} \text { in } 300 \mathrm{~min}(\mathrm{HES}) \text {, } \\
\text { administered as } 20 \mathrm{~mL} / \mathrm{kg} / \mathrm{h} \\
\text { in the first hour and } 5 \mathrm{~mL} / \mathrm{kg} / \mathrm{h} \\
\text { for the remaining duration of } \\
\text { the protocol } \\
\text { b) Late resuscitation group } \\
30 \mathrm{~mL} / \mathrm{kg} \text { in } 300 \mathrm{~min}(\mathrm{HES}), \\
\text { administered as } 20 \mathrm{~mL} / \mathrm{kg} / \mathrm{h} \\
\text { in the first hour and } 5 \mathrm{~mL} / \mathrm{kg} / \mathrm{h} \\
\text { for the remaining duration of } \\
\text { the protocol }\end{array}$ & $\begin{array}{l}\text { Despite immediate } \\
\text { hydroxyethyl starch fluid } \\
\text { resuscitation being better } \\
\text { than delayed resuscitation, } \\
\text { overall prevention of renal } \\
\text { macrovascular hypoperfusion } \\
\text { did not fully prevent renal } \\
\text { microcirculatory dysfunction }\end{array}$ & $\begin{array}{l}\text { Test hypothesis that } \\
\text { prevention of endotoxaemia- } \\
\text { induced hypotension by im } \\
\text { mediate fluid resuscitation } \\
\text { would prevent development } \\
\text { of renal microcirculatory } \\
\text { dysfunction }\end{array}$ \\
\hline $\begin{array}{l}\text { Andersson } \\
\text { et al. [15] }\end{array}$ & 2012 & Sheep & (5 and 8) & $\begin{array}{l}\text { Laser Doppler flowmetry and sidestream } \\
\text { dark-field videomicroscopy: } \\
\text { Microcirculation was assessed by the } \\
\text { following measurements obtained from }\end{array}$ & $\begin{array}{l}\text { a) LPS group } \\
519 \pm \text { (SD) } 342 \mathrm{~mL} \text { (HES) }\end{array}$ & $\begin{array}{l}\text { Microcirculatory dysfunction } \\
\text { persisted in fluid resuscitated } \\
\text { endotoxaemic shock despite } \\
\text { increased regional blood flow }\end{array}$ & $\begin{array}{l}\text { Test hypothesis that in } \\
\text { hyperdynamic endotoxaemic } \\
\text { shock, intestinal } \\
\text { microcirculatory dysfunction }\end{array}$ \\
\hline
\end{tabular}


Table 1 Animal model studies assessing effects of volume resuscitation on the microcirculation in lipopolysaccharide-induced sepsis (Continued)

\begin{tabular}{|c|c|c|c|c|c|c|c|}
\hline & & & & $\begin{array}{l}\text { five sites in the ileal mucosa, with each } \\
\text { site divided into } 4 \text { quadrants at } \\
\text { each time-point. } \\
\text { (a) Microvascular flow index, MFI } \\
\text { [i.e. average flow of all quadrants } \\
\text { scored as no flow (0), intermittent } \\
\text { flow (1), sluggish flow (2) or } \\
\text { continuous flow (3)] } \\
\text { (b) Percentage of perfused villi, PV\% } \\
\text { [i.e. the number of villi in each video } \\
\text { were counted and semi-quantitatively } \\
\text { classified as perfused, heterogeneously } \\
\text { perfused or unperfused; PV\% was } \\
\text { calculated as number of perfused villi } \\
\text { divided by the total number of villi] } \\
\text { (c) Heterogeneity index, HI [i.e. highest } \\
\text { flow velocity minus lowest flow } \\
\text { velocity divided by the mean MFI] }\end{array}$ & & & $\begin{array}{l}\text { will be present despite } \\
\text { increased regional blood flow }\end{array}$ \\
\hline $\begin{array}{l}\text { Duburcq } \\
\text { et al. [65] }\end{array}$ & 2014 & Pig & 5 & $\begin{array}{l}\text { Laser Doppler flowmetry: } \\
\text { Microcirculation was assessed on the } \\
\text { skin blood flow using laser Doppler } \\
\text { measurements expressed in arbitrary } \\
\text { perfusion units, PU [i.e. peak flow was } \\
\text { defined as the highest flow signal } \\
\text { obtained post-pneumatic occlusion } \\
\text { of blood flow to the legs. Duration of } \\
\text { the flow signal was also recorded] }\end{array}$ & $\begin{array}{l}\text { a) } 0.9 \% \text { sodium chloride } \\
\text { group } 5 \mathrm{~mL} / \mathrm{kg} / \mathrm{h} \\
\text { b) } 8.4 \% \text { hypertonic sodium } \\
\text { bicarbonate } 5 \mathrm{~mL} / \mathrm{kg} / \mathrm{h} \\
\text { c) } 11.2 \% \text { hypertonic sodium } \\
\text { lactate } 5 \mathrm{~mL} / \mathrm{kg} / \mathrm{h}\end{array}$ & $\begin{array}{l}\text { Hypertonic sodium lactate } \\
\text { solution improves microvascular } \\
\text { reactivity with a negative fluid } \\
\text { balance }\end{array}$ & $\begin{array}{l}\text { Investigate effects of } \\
\text { hypertonic sodium lactate } \\
\text { compared to sodium chloride } \\
\text { on the microcirculation in } \\
\text { endotoxic shock }\end{array}$ \\
\hline $\begin{array}{l}\text { Lopez } \\
\text { et al. [51] }\end{array}$ & 2015 & Pig & - & $\begin{array}{l}\text { Sidestream dark-field videomicroscopy: } \\
\text { Microcirculation was assessed by the } \\
\text { following measurements obtained } \\
\text { from the average of } 12 \text { quadrants } \\
\text { (i.e. three videos of sublingual mucosa, } \\
\text { four quadrants each); } \\
\text { (a) Microvascular density, MVD } \\
\text { [i.e. number of vessels per } \mathrm{mm}^{2} \\
\text { in sublingual mucosa] }\end{array}$ & $\begin{array}{l}\text { a) LPS group } 8 \mathrm{~mL} / \mathrm{kg} / \mathrm{h} \text { (saline) } \\
\text { b) Early resuscitation protocol, ERP } \\
250 \mathrm{~mL} / \mathrm{h} \text { for } 2 \mathrm{~h} \text { (Haemacell) } \\
\text { c) Sham } 8 \mathrm{~mL} / \mathrm{kg} / \mathrm{h} \text { (saline) }\end{array}$ & $\begin{array}{l}\text { Early resuscitation restored } \\
\text { macro-haemodynamic } \\
\text { parameters but microcirculatory } \\
\text { alterations persisted }\end{array}$ & $\begin{array}{l}\text { Assess systemic and } \\
\text { microcirculatory correlation } \\
\text { of early resuscitation for } \\
\text { endotoxic shock }\end{array}$ \\
\hline
\end{tabular}


Table 1 Animal model studies assessing effects of volume resuscitation on the microcirculation in lipopolysaccharide-induced sepsis (Continued)

$$
\begin{aligned}
& \text { (b) Microvascular flow index, MFI } \\
& \text { [i.e. average flow of individual } \\
& \text { vessels scored as no flow (0), } \\
& \text { intermittent flow (1), sluggish } \\
& \text { flow (2) or continuous flow (3)] } \\
& \text { (c) Heterogeneity flow index, HFI } \\
& \text { [i.e. highest MFI minus lowest } \\
& \text { MFI divided by mean MFI] } \\
& \text { (d) Proportion of perfused vessels, PPV } \\
& \text { [i.e. total number of vessels minus } \\
& \text { number of vessels with flow }=0 \text { or } 1 \\
& \text { divided by total number of vessels] } \\
& \text { (e) Perfused vessel density, PVD }
\end{aligned}
$$


significant challenge. We considered some of these, including videomicroscopic techniques, whilst offering direct visualization of the microcirculation, the tissue contact element is largely uncontrolled and may cause pressure-induced artefacts. On the other hand, laser techniques are susceptible to motion artefacts, so that combining techniques might enhance the accuracy of microcirculatory assessments [76]. Only one study presented in this review used a combination of techniques to assess the microcirculation (i.e., laser Doppler flowmetry and sidestream dark-field imaging) and reported persistent acidosis, microcirculatory and mitochondrial dysfunction despite resuscitation with hydroxyethyl starch (HES) fluid [15]. Routine microcirculation assessment is rarely performed owing to heterogeneity of microvascular beds in different organs and complexity of assessment techniques. There was significant heterogeneity in the type and volume of resuscitation fluids used in the studies presented in this review. Clinically, substantial controversy still surrounds the choice of fluid for resuscitation. The Saline versus Albumin Fluid Evaluation (SAFE) study in adults similarly failed to identify any significant difference in the sepsis sub-group of patients [78], despite a lower unadjusted relative risk of death for albumin versus saline compared with non-septic patients [79]. The Crystalloid versus Hydroxyethyl Starch Trial (CHEST) revealed an increased rate of renal replacement therapy and adverse events (pruritus, rash) in intensive care unit patients resuscitated using colloid (6\% hydroxyethyl starch, HES) compared to crystalloid ( $0.9 \%$ saline), with no significant difference in the 90-day mortality between the two groups [80]. For paediatric sepsis, the evidence base for fluid resuscitation upon definitive choices of fluids for resuscitation in severe infection and shock remains very weak [81], with most studies providing low quality of evidence or focusing on malaria and dengue. The FEAST trial documented a $45 \%$ relative (95\% confidence interval, CI 13-86\%) increase in 48-h mortality compared to control, with no significant difference between the saline and albumin bolus arms [57]. A subsequent systematic review formally assessing the evidence for bolus fluid resuscitation included 13 studies which met the inclusion criteria (4 general shock, 4 malaria, 4 dengue and 1 severe malnutrition). None were conducted in high-income countries and the only study to include a control arm (i.e. no fluid bolus arm; FEAST trial), found at $48 \mathrm{~h}$ a lower mortality in controls compared to those receiving saline or colloid boluses (relative risk for sepsis $0.69,95 \%$ CI 0.54-0.89 and for malaria 0.64, 95\% CI 0.46-0.91, respectively) [82]. Similarly, other studies have reported higher rates of morbidity and mortality with positive fluid balance in septic shock [83-89] and one retrospective pilot study reported good prognosis in patients who achieved a negative fluid balance within the first 3 days of septic shock [90]. Previous research showing transient pulmonary arterial hypertension that was induced by transfusion with donor blood, which had been stored for 35-42 days, is suggestive of a two-hit hypothesis that can be extrapolated to sepsis (first-hit) and volume resuscitation (second-hit) [91].

The pathogenesis of sepsis is complex, and evidence of higher rates of mortality with volume resuscitation therapy has led to the development of a two-hit hypothesis, highlighting the need for further mechanistic studies. Similarly, the heterogeneity in monitoring targets to guide resuscitation in septic shock has been recently highlighted [53-55]. Novel approaches and consensus in monitoring targets are required to preserve and evaluate the microcirculation in order to improve the treatment of sepsis. 


\section{Conclusions}

Microcirculatory resuscitation is an important therapeutic goal, as restoration of the macro-circulation alone fails to improve microvascular function. Transferring wetbench discoveries to the clinical setting requires biologically relevant animal model studies to understand both the mechanisms by which fluid resuscitation affects the microcirculation and the role of the endothelial-glycocalyx in sepsis. One important priority for mechanistic research in sepsis is to compare the microcirculatory indices and outcomes achieved with different resuscitation strategies. Further research with defined therapeutic end-points and standardized fluid and microcirculatory assessment protocol is required as it remains unclear whether the heterogeneity that was seen was a result of the model used, resuscitation fluids used or the microcirculatory assessment techniques.

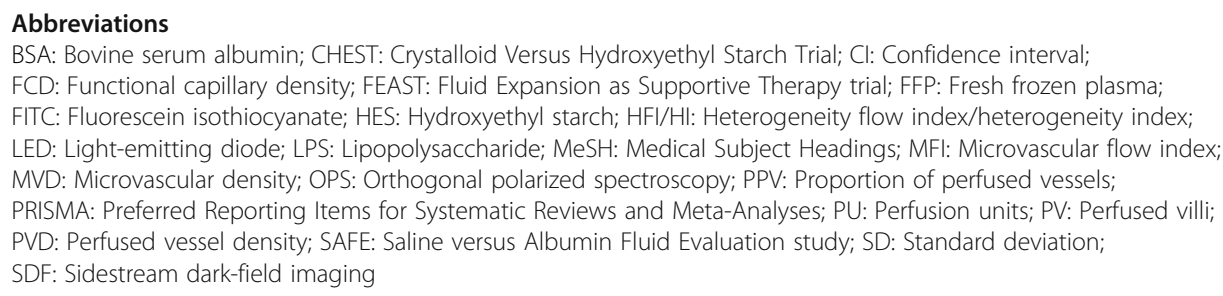

\section{Acknowledgements}

The authors would like to thank Dr. Liam Byrne, Ms. Sara Diab, Mr. Kimble Dunster as well as the RESUS ovine trial investigators and collaborators.

\section{Funding}

Not applicable.

Availability of data and materials

The datasets supporting the conclusions of this article are available in PubMed/MEDLINE

(http://www.ncbi.nlm.nih.gov/pubmed) and EMBASE (https://www.elsevier.com/journals/title/all).

\section{Authors' contributions}

NGO, JPF, KS, DGP, KM and JFF designed and planned the study as part of collaboration between the Critical Care Research Group, Australia; KEMRI-Wellcome Trust Research Programme, Kenya and Imperial College London, UK. NGO, JPF, AN and LPP conducted the systematic literature search. NGO and KS conducted the statistical analysis. NGO, JPF, KS, DGP, KM and JFF were involved in the interpretation of analysed data and drawing conclusions from the analysis. NGO drafted the original manuscript with all authors commenting on drafts, revisions and approving the final manuscript.

\section{Competing interests}

The authors declare that they have no competing interests.

\section{Consent for publication}

Not applicable.

\section{Ethics approval and consent to participate}

Not applicable.

\section{Author details}

${ }^{1}$ Critical Care Research Group, The Prince Charles Hospital, Brisbane, Queensland, Australia. ${ }^{2}$ Kenya Medical Research Institute-Wellcome Trust Research Programme, Kilifi, Kenya. ${ }^{3}$ School of Medicine, University of Queensland, Brisbane, Queensland, Australia. ${ }^{4}$ Department of Paediatrics, Faculty of Medicine, Imperial College London, London, UK.

Received: 2 July 2016 Accepted: 15 November 2016

Published online: 21 November 2016

\section{References}

1. Singer M, Deutschman CS, Seymour CW, Shankar-Hari M, Annane D, Bauer M, Bellomo R, Bernard GR, Chiche JD, Coopersmith CM et al (2016) The Third International Consensus Definitions for Sepsis and Septic Shock (Sepsis-3). JAMA 315(8):801-810

2. Jawad I, Luksic I, Rafnsson SB (2012) Assessing available information on the burden of sepsis: global estimates of incidence, prevalence and mortality. J Glob Health 2(1):010404 
3. Brierley J, Carcillo JA, Choong K, Cornell T, Decaen A, Deymann A, Doctor A, Davis A, Duff J, Dugas MA et al (2009) Clinical practice parameters for hemodynamic support of pediatric and neonatal septic shock: 2007 update from the American College of Critical Care Medicine. Crit Care Med 37(2):666-688

4. Kleinman ME, de Caen AR, Chameides L, Atkins DL, Berg RA, Berg MD, Bhanji F, Biarent D, Bingham R, Coovadia AH et al (2010) Part 10: Pediatric basic and advanced life support: 2010 International Consensus on Cardiopulmonary Resuscitation and Emergency Cardiovascular Care Science With Treatment Recommendations. Circulation 122(16 Suppl 2):S466-S515

5. Kleinman ME, Chameides L, Schexnayder SM, Samson RA, Hazinski MF, Atkins DL, Berg MD, de Caen AR, Fink EL, Freid EB et al (2010) Part 14: pediatric advanced life support: 2010 American Heart Association Guidelines for Cardiopulmonary Resuscitation and Emergency Cardiovascular Care. Circulation 122(18 Suppl 3):S876-S908

6. Anderson MR, Blumer JL (1997) Advances in the therapy for sepsis in children. Pediatr Clin North Am 44(1):179-205

7. Dellinger RP, Levy MM, Rhodes A, Annane D, Gerlach H, Opal SM, Sevransky JE, Sprung CL, Douglas IS, Jaeschke R et al (2013) Surviving sepsis campaign: international guidelines for management of severe sepsis and septic shock: 2012. Crit Care Med 41(2):580-637

8. WHO (2013) Pocket book of hospital care for children, 2nd edn, Guidelines for the management of common childhood illnesses

9. Carcillo JA, Davis AL, Zaritsky A (1991) Role of early fluid resuscitation in pediatric septic shock. JAMA 266(9):1242-1245

10. Nakajima Y, Baudry N, Duranteau J, Vicaut E (2001) Microcirculation in intestinal villi: a comparison between hemorrhagic and endotoxin shock. Am J Respir Crit Care Med 164(8 Pt 1):1526-1530

11. Sakr Y, Dubois MJ, De Backer D, Creteur J, Vincent JL (2004) Persistent microcirculatory alterations are associated with organ failure and death in patients with septic shock. Crit Care Med 32(9):1825-1831

12. Hardaway RM (2000) A review of septic shock. Am Surg 66(1):22-29

13. Nacul FE, Guia IL, Lessa MA, Tibirica E (2010) The effects of vasoactive drugs on intestinal functional capillary density in endotoxemic rats: intravital video-microscopy analysis. Anesth Analg 110(2):547-554

14. Schmidt C, Lautenschläger C, Petzold B, Marx G, Stallmach A (2012) Confocal laser endomicroscopy to assess mucosal microcirculation: a quantitative analysis in a porcine model of septic shock and in patients with severe sepsis. Gastroenterology 142(5):S7

15. Andersson A, Rundgren M, Kalman S, Rooyackers O, Brattstrom O, Oldner A, Eriksson S, Frithiof R (2012) Gut microcirculatory and mitochondrial effects of hyperdynamic endotoxaemic shock and norepinephrine treatment. Br J Anaesth 108(2):254-261

16. Spronk PE, Zandstra DF, Ince C (2004) Bench-to-bedside review: sepsis is a disease of the microcirculation. Crit Care 8(6):462-468

17. Ince C (2005) The microcirculation is the motor of sepsis. Crit Care 9(Suppl 4):S13-S19

18. Vincent JL, De Backer D (2005) Microvascular dysfunction as a cause of organ dysfunction in severe sepsis. Crit Care 9(Suppl 4):S9-S12

19. Bellapart J, Dunster KR, Diab S, Platts DG, Raffel C, Gabrielian L, Maybauer MO, Barnett A, Boots RJ, Fraser JF (2013) Intracardiac echocardiography guided transeptal catheter injection of microspheres for assessment of cerebral microcirculation in experimental models. Cardiol Res Pract 2013:595838

20. Moore JP, Dyson A, Singer M, Fraser J (2015) Microcirculatory dysfunction and resuscitation: why, when, and how. $\mathrm{Br} J$ Anaesth 115(3):366-375

21. Boerma EC, Mathura KR, van der Voort PH, Spronk PE, Ince C (2005) Quantifying bedside-derived imaging of microcirculatory abnormalities in septic patients: a prospective validation study. Crit Care 9(6):R601-R606

22. Chappell D, Westphal M, Jacob M (2009) The impact of the glycocalyx on microcirculatory oxygen distribution in critical illness. Curr Opin Anaesthesiol 22(2):155-162

23. Ince C, Sinaasappel M (1999) Microcirculatory oxygenation and shunting in sepsis and shock. Crit Care Med 27(7):1369-1377

24. Lush CW, Kvietys PR (2000) Microvascular dysfunction in sepsis. Microcirculation 7(2):83-101

25. Lehr HA, Bittinger F, Kirkpatrick CJ (2000) Microcirculatory dysfunction in sepsis: a pathogenetic basis for therapy? J Pathol 190(3):373-386

26. De Backer D, Creteur J, Preiser JC, Dubois MJ, Vincent JL (2002) Microvascular blood flow is altered in patients with sepsis. Am J Respir Crit Care Med 166(1):98-104

27. Bateman RM, Sharpe MD, Ellis CG (2003) Bench-to-bedside review: microvascular dysfunction in sepsis-hemodynamics, oxygen transport, and nitric oxide. Crit Care 7(5):359-373

28. Tyagi A, Sethi AK, Girotra G, Mohta M (2009) The microcirculation in sepsis. Indian J Anaesth 53(3):281-293

29. Edul VK, Ferrara G, Dubin A (2010) Microcirculatory dysfunction in sepsis. Endocr Metab Immune Disord Drug Targets 10(3):235-246

30. Spanos A, Jhanji S, Vivian-Smith A, Harris T, Pearse RM (2010) Early microvascular changes in sepsis and severe sepsis. Shock 33(4):387-391

31. Lundy DJ, Trzeciak S (2011) Microcirculatory dysfunction in sepsis. Crit Care Nurs Clin North Am 23(1):67-77

32. Ratiani L, Gamkrelidze M, Khuchua E, Khutsishvili T, Intskirveli N, Vardosanidze K (2015) Altered microcirculation in septic shock. Georgian Med News (244-245):16-24

33. Coletta C, Modis K, Olah G, Brunyanszki A, Herzig DS, Sherwood ER, Ungvari Z, Szabo C (2014) Endothelial dysfunction is a potential contributor to multiple organ failure and mortality in aged mice subjected to septic shock: preclinical studies in a murine model of cecal ligation and puncture. Crit Care 18(5):511

34. Trzeciak S, Dellinger RP, Parrillo JE, Guglielmi M, Bajaj J, Abate NL, Arnold RC, Colilla S, Zanotti S, Hollenberg SM et al (2007) Early microcirculatory perfusion derangements in patients with severe sepsis and septic shock: relationship to hemodynamics, oxygen transport, and survival. Ann Emerg Med 49(1):88-98, 98 e81-82

35. Straat M, Muller MC, Meijers JC, Arbous MS, Spoelstra-de Man AM, Beurskens CJ, Vroom MB, Juffermans NP (2015) Effect of transfusion of fresh frozen plasma on parameters of endothelial condition and inflammatory status in non-bleeding critically ill patients: a prospective substudy of a randomized trial. Crit Care 19:163 
36. Trzeciak S, McCoy JV, Phillip Dellinger R, Arnold RC, Rizzuto M, Abate NL, Shapiro NI, Parrillo JE, Hollenberg SM, Microcirculatory Alterations in $\mathrm{R}$ et al (2008) Early increases in microcirculatory perfusion during protocol-directed resuscitation are associated with reduced multi-organ failure at $24 \mathrm{~h}$ in patients with sepsis. Intensive Care Med 34(12):2210-2217

37. Buchele GL, Ospina-Tascon GA, De Backer D (2007) How microcirculation data have changed my clinical practice. Curr Opin Crit Care 13(3):324-331

38. Goedhart PT, Khalilzada M, Bezemer R, Merza J, Ince C (2007) Sidestream Dark Field (SDF) imaging: a novel stroboscopic LED ring-based imaging modality for clinical assessment of the microcirculation. Opt Express 15(23):15101-15114

39. Pittet MJ, Weissleder R (2011) Intravital imaging. Cell 147(5):983-991

40. Menger MD, Lehr HA (1993) Scope and perspectives of intravital microscopy-bridge over from in vitro to in vivo. Immunol Today 14(11):519-522

41. Briers JD (2001) Laser Doppler, speckle and related techniques for blood perfusion mapping and imaging. Physiol Meas 22(4):R35-R66

42. Draijer M, Hondebrink E, van Leeuwen T, Steenbergen W (2009) Review of laser speckle contrast techniques for visualizing tissue perfusion. Lasers Med Sci 24(4):639-651

43. Holloway GA Jr, Watkins DW (1977) Laser Doppler measurement of cutaneous blood flow. J Invest Dermatol 69(3):306-309

44. Turner J, Belch JJ, Khan F (2008) Current concepts in assessment of microvascular endothelial function using laser Doppler imaging and iontophoresis. Trends Cardiovasc Med 18(4):109-116

45. Fullerton A, Stucker M, Wilhelm KP, Wardell K, Anderson C, Fischer T, Nilsson GE, Serup J, European Society of Contact Dermatitis Standardization G (2002) Guidelines for visualization of cutaneous blood flow by laser Doppler perfusion imaging. A report from the Standardization Group of the European Society of Contact Dermatitis based upon the HIRELADO European community project. Contact Dermatitis 46(3):129-140

46. Han YY, Carcillo JA, Dragotta MA, Bills DM, Watson RS, Westerman ME, Orr RA (2003) Early reversal of pediatricneonatal septic shock by community physicians is associated with improved outcome. Pediatrics 112(4):793-799

47. Rivers E, Nguyen B, Havstad S, Ressler J, Muzzin A, Knoblich B, Peterson E, Tomlanovich M, Early Goal-Directed Therapy Collaborative G (2001) Early goal-directed therapy in the treatment of severe sepsis and septic shock. N Engl J Med 345(19):1368-1377

48. Schick MA, Isbary JT, Stueber T, Brugger J, Stumpner J, Schlegel N, Roewer N, Eichelbroenner O, Wunder C (2012) Effects of crystalloids and colloids on liver and intestine microcirculation and function in cecal ligation and puncture induced septic rodents. BMC Gastroenterol 12:179

49. Ergin B, Zafrani L, Kandil A, Baasner S, Lupp C, Demirci C, Westphal M, Ince C (2016) Fully balanced fluids do not improve microvascular oxygenation, acidosis and renal function in a rat model of endotoxemia. Shock 46(1):83-91

50. Aksu U, Bezemer R, Demirci C, Ince C (2012) Acute effects of balanced versus unbalanced colloid resuscitation on renal macrocirculatory and microcirculatory perfusion during endotoxemic shock. Shock 37(2):205-209

51. Lopez A, Grignola JC, Angulo M, Alvez I, Nin N, Lacuesta G, Baz M, Cardinal P, Prestes I, Bouchacourt JP et al (2015) Effects of early hemodynamic resuscitation on left ventricular performance and microcirculatory function during endotoxic shock. Intensive Care Med Exp 3(1):49

52. Legrand M, Bezemer R, Kandil A, Demirci C, Payen D, Ince C (2011) The role of renal hypoperfusion in development of renal microcirculatory dysfunction in endotoxemic rats. Intensive Care Med 37(9):1534-1542

53. Investigators A, Group ACT, Peake SL, Delaney A, Bailey M, Bellomo R, Cameron PA, Cooper DJ, Higgins AM, Holdgate A et al (2014) Goal-directed resuscitation for patients with early septic shock. N Engl J Med 371(16):1496-1506

54. Pro Cl, Yealy DM, Kellum JA, Huang DT, Barnato AE, Weissfeld LA, Pike F, Terndrup T, Wang HE, Hou PC et al (2014) A randomized trial of protocol-based care for early septic shock. N Engl J Med 370(18):1683-1693

55. Mouncey PR, Osborn TM, Power GS, Harrison DA, Sadique MZ, Grieve RD, Jahan R, Harvey SE, Bell D, Bion JF et al (2015) Trial of early, goal-directed resuscitation for septic shock. N Engl J Med 372(14):1301-1311

56. Delaney AP, Dan A, McCaffrey J, Finfer S (2011) The role of albumin as a resuscitation fluid for patients with sepsis: a systematic review and meta-analysis. Crit Care Med 39(2):386-391

57. Maitland K, Kiguli S, Opoka RO, Engoru C, Olupot-Olupot P, Akech SO, Nyeko R, Mtove G, Reyburn H, Lang T et al (2011) Mortality after fluid bolus in African children with severe infection. N Engl J Med 364(26):2483-2495

58. Perel P, Roberts I (2007) Colloids versus crystalloids for fluid resuscitation in critically ill patients. Cochrane Database Syst Rev 4:CD000567

59. Perel P, Roberts I, Sena E, Wheble P, Briscoe C, Sandercock P, Macleod M, Mignini LE, Jayaram P, Khan KS (2007) Comparison of treatment effects between animal experiments and clinical trials: systematic review. BMJ 334(7586):197

60. Moher D, Liberati A, Tetzlaff J, Altman DG, Group P (2009) Preferred reporting items for systematic reviews and meta-analyses: the PRISMA statement. PLoS Med 6(7):e1000097

61. de Carvalho H, Matos JA, Bouskela E, Svensjo E (1999) Vascular permeability increase and plasma volume loss induced by endotoxin was attenuated by hypertonic saline with or without dextran. Shock 12(1):75-80

62. Hoffmann JN, Vollmar B, Laschke MW, Inthorn D, Schildberg FW, Menger MD (2002) Hydroxyethyl starch (130 kD), but not crystalloid volume support, improves microcirculation during normotensive endotoxemia. Anesthesiology 97(2):460-470

63. Anning PB, Finney SJ, Singh S, Winlove CP, Evans TW (2004) Fluids reverse the early lipopolysaccharide-induced albumin leakage in rodent mesenteric venules. Intensive Care Med 30(10):1944-1949

64. Oi Y, Aneman A, Svensson M, Ewert S, Dahlqvist M, Haljamae H (2000) Hypertonic saline-dextran improves intestinal perfusion and survival in porcine endotoxin shock. Crit Care Med 28(8):2843-2850

65. Duburcq T, Favory R, Mathieu D, Hubert T, Mangalaboyi J, Gmyr V, Quintane L, Maboudou P, Pattou F, Jourdain M (2014) Hypertonic sodium lactate improves fluid balance and hemodynamics in porcine endotoxic shock. Crit Care 18(4):467

66. Maciel F, Mook M, Zhang H, Vincent JL (1998) Comparison of hypertonic with isotonic saline hydroxyethyl starch solution on oxygen extraction capabilities during endotoxic shock. Shock 9(1):33-39 
67. Zhang H, Smail N, Cabral A, Cherkaoui S, Peny MO, Vincent JL (1999) Hepato-splanchnic blood flow and oxygen extraction capabilities during experimental tamponade: effects of endotoxin. J Surg Res 81(2):129-138

68. Dubin A, Edul VS, Pozo MO, Murias G, Canullan CM, Martins EF, Ferrara G, Canales HS, Laporte M, Estenssoro E et al (2008) Persistent villi hypoperfusion explains intramucosal acidosis in sheep endotoxemia. Crit Care Med 36(2):535-542

69. Astiz ME, DeGent GE, Lin RY, Rackow EC (1995) Microvascular function and rheologic changes in hyperdynamic sepsis. Crit Care Med 23(2):265-271

70. Linderkamp O, Ruef P, Brenner B, Gulbins E, Lang F (1998) Passive deformability of mature, immature, and active neutrophils in healthy and septicemic neonates. Pediatr Res 44(6):946-950

71. Poschl JM, Leray C, Ruef P, Cazenave JP, Linderkamp O (2003) Endotoxin binding to erythrocyte membrane and erythrocyte deformability in human sepsis and in vitro. Crit Care Med 31(3):924-928

72. Becker BF, Chappell D, Bruegger D, Annecke T, Jacob M (2010) Therapeutic strategies targeting the endothelial glycocalyx: acute deficits, but great potential. Cardiovasc Res 87(2):300-310

73. Ignarro L, Buga GM, Wood KS, Byrns RE, Chaudhuri G (1987) Endothelium-derived relaxing factor produced and released from artery and vein is nitric oxide. Proc Natl Acad Sci U S A 84(24):9265-9269

74. Yvonne-Tee GB, Rasool AH, Halim AS, Rahman AR (2006) Noninvasive assessment of cutaneous vascular function in vivo using capillaroscopy, plethysmography and laser-Doppler instruments: its strengths and weaknesses. Clin Hemorheol Microcirc 34(4):457-473

75. Treu CM, Lupi O, Bottino DA, Bouskela E (2011) Sidestream dark field imaging: the evolution of real-time visualization of cutaneous microcirculation and its potential application in dermatology. Arch Dermatol Res 303(2):69-78

76. Eriksson S, Nilsson J, Sturesson C (2014) Non-invasive imaging of microcirculation: a technology review. Med Devices (Auckl) 7:445-452

77. LaRouere MJ, Sillman JS, Nuttall AL, Miller JM (1989) A comparison of laser Doppler and intravital microscopic measures of cochlear blood flow. Otolaryngol Head Neck Surg 101(3):375-384

78. Finfer S, Bellomo R, Boyce N, French J, Myburgh J, Norton R, Investigators SS (2004) A comparison of albumin and saline for fluid resuscitation in the intensive care unit. N Engl J Med 350(22):2247-2256

79. Investigators SS, Finfer S, McEvoy S, Bellomo R, McArthur C, Myburgh J, Norton R (2011) Impact of albumin compared to saline on organ function and mortality of patients with severe sepsis. Intensive Care Med 37(1):86-96

80. Myburgh JA, Finfer S, Bellomo R, Billot L, Cass A, Gattas D, Glass P, Lipman J, Liu B, McArthur C et al (2012) Hydroxyethyl starch or saline for fluid resuscitation in intensive care. N Engl J Med 367(20):1901-1911

81. Akech S, Ledermann H, Maitland K (2010) Choice of fluids for resuscitation in children with severe infection and shock: systematic review. BMJ 341:C4416

82. Ford N, Hargreaves S, Shanks L (2012) Mortality after fluid bolus in children with shock due to sepsis or severe infection: a systematic review and meta-analysis. PLoS One 7(8):e43953

83. Boyd JH, Forbes J, Nakada TA, Walley KR, Russell JA (2011) Fluid resuscitation in septic shock: a positive fluid balance and elevated central venous pressure are associated with increased mortality. Crit Care Med 39(2):259-265

84. Sadaka F, Juarez M, Naydenov S, O'Brien J (2014) Fluid resuscitation in septic shock: the effect of increasing fluid balance on mortality. J Intensive Care Med 29(4):213-217

85. Flori HR, Church G, Liu KD, Gildengorin G, Matthay MA (2011) Positive fluid balance is associated with higher mortality and prolonged mechanical ventilation in pediatric patients with acute lung injury. Crit Care Res Prac 2011:854142

86. van der Heijden M, Pickkers P, van Nieuw Amerongen GP, van Hinsbergh WW, Bouw MP, van der Hoeven JG, Groeneveld AB (2009) Circulating angiopoietin-2 levels in the course of septic shock: relation with fluid balance, pulmonary dysfunction and mortality. Intensive Care Med 35(9):1567-1574

87. Murphy CV, Schramm GE, Doherty JA, Reichley RM, Gajic O, Afessa B, Micek ST, Kollef MH (2009) The importance of fluid management in acute lung injury secondary to septic shock. Chest 136(1):102-109

88. Vincent JL, Sakr Y, Sprung CL, Ranieri VM, Reinhart K, Gerlach H, Moreno R, Carlet J, Le Gall JR, Payen D et al (2006) Sepsis in European intensive care units: results of the SOAP study. Crit Care Med 34(2):344-353

89. Sakr Y, Vincent JL, Reinhart K, Groeneveld J, Michalopoulos A, Sprung CL, Artigas A, Ranieri VM, Sepsis Occurence in Acutely III Patients I (2005) High tidal volume and positive fluid balance are associated with worse outcome in acute lung injury. Chest 128(5):3098-3108

90. Alsous F, Khamiees M, DeGirolamo A, Amoateng-Adjepong Y, Manthous CA (2000) Negative fluid balance predicts survival in patients with septic shock: a retrospective pilot study. Chest 117(6):1749-1754

91. Fung YL, Tung JP, Foley SR, Simonova G, Thom O, Staib A, Collier J, Dunster KR, Solano C, Shekar K et al (2013) Stored blood transfusion induces transient pulmonary arterial hypertension without impairing coagulation in an ovine model of nontraumatic haemorrhage. Vox Sang 105(2):150-158 